Volume 7 Issue 2, June 2020

Nationally Accredited Journal,

Decree No. B/4130/E5/E5.2.1/2019

\title{
The Implementation of Legal Responsibilities Of Notary on Authentic Deed Which His Made Based On Act No. 2 of 2014 On the Amendment of Act No. 30 of 2004 On Notary in Kendari
}

\author{
Zahren Zukri Alyafie ${ }^{1}$, Andi Kusuma Mapareppa ${ }^{2}$ and Amin \\ Purnawan ${ }^{3}$
}

\begin{abstract}
This study aims 1) To determine the implementation of the Civil Liability of the Deed Notary in Authentic are made according to Act No. 2 of 2014 on the Amendment of Act No. 30 of 2004 On Notary in Kendari; 2) To determine the barriers and solutions in the Implementation Responsibility Against Notary Authentic Deed had made in Kendari.

This study uses empirical juridical approach, the specification of this research is descriptive. The type of data in this study include primary data and secondary data. Data obtainedthe method of interview and literature. Data analysis technique is qualitative.

Based on this study concluded that: 1)Implementation of the Notary in Civil Responsibility of the Authentic Deed Which His Made, notary only responsible for the formal correctness of an Authentic Deed and not to the authentic deed material. The legal basis used in civil liability against the deed made by Notary Public Notary is if make mistakes because of broken promises as determined under the provisions of Article 1234 of the Civil Code and against the law as stipulated in the provisions of Article 1365 of the Civil Code. 2) Obstacles and Solutions in Implementation of Notary Responsibility of the Authentic Deed Which His Made, namely: a) Obstacles in the Implementation Responsibility The Notary of the Authentic Deed he made, when one of the parties then feel there are disadvantaged in this regard is the responsibility of the parties is not the responsibility of the notary. Precisely deed made by the notary is evidence that can be used by the parties. b) Solutions in the Implementation of Notary Responsibility of the Authentic Deed Which His Made If proved, no offense will be undertaken by the notary and harm either party in because a deed in him. The civil claims against the notary concerned civilly liable if proven.

Keywords: Legal Responsibilities; Notary Public; Authentic Deed.
\end{abstract}

\section{Introduction}

Notary Public is a professional designation for someone who has gained legal education licensed by the government to do things the law, particularly as a witness to the signing of the document. ${ }^{4}$

Understanding Civil Law Notary in the system provided for in Article 1 Ord, stbl. 1860 No. 3 On Notary in Indonesia came into force on 1 July 1860 which was then translated by Soegondo Notodisoedo (1993) states that the definition of Notaries are

\footnotetext{
${ }^{1}$ Students of Master of Notary Program, Faculty of Law, Sultan Agung Islamic University (UNISSULA), Semarang, email: zahren zukri@yahoo.com

${ }^{2}$ Student of Master of Law Program, Faculty of Law, Universitas Islam Sultan Agung email shumaa26@gmail.com

${ }^{3}$ Lecturer of Master of Notary Program, Sultan Agung Islamic University (UNISSULA), Semarang

${ }^{4}$ https://id.wikipedia.org/wiki/Notaris (Accessed on October 2, 2019 at 1:08 pm).
} 
as follows: ${ }^{5}$

Notary is a public official, in particular (only) that is authorized to make the deeds authentic about all actions, agreements and decisions required by general legislation to desired by the concerned that it is stated in the letter is authentic, guarantee date, storing and issuing deeds of grosse, copies (derivatives) and quotations, all of it if the making of such deeds or devoted to the officials or others.

Notary in performing a task, whether it is the duty of office or professional duties, each implementation takes the responsibility of each individual who run them. Because of it's own responsibility arising from the responsibility gets a trust to carry out a task or to get a trust or for getting the mandate to occupy a position or positions.

Notary as one of law enforcement for the Notary make written evidence possessed the strength of evidence. The jurists found notarial deed can be accepted in court as evidence of absolute about it, but nevertheless are held denials with evidence to the contrary by the witnesses, who can prove that what was described by the Notary in the deed is true. ${ }^{6}$

However Notary is not responsible for omissions and errors in the content deed made before him, but the Notary is responsible only formal form Authentic Deed in accordance with what is implied in Article 65 of Act No. 2 of 2014 concerning amendments to the Act No. 30 Of 2004 on Position notary who states that: ${ }^{7}$

"Notaries, Notary Substitute, and Acting Notary responsible for any deed that is made despite the Protocol Notary has been assigned or transferred to the storage Notary Protocol."

Regarding the responsibility of the Notary as public officials related to the material truth can be divided into four points, namely:

- Notary responsibility to the truth of the deed he had made material;

- Notary civilly liable to the material truth in deed he made;

- Notary responsibilities pursuant to Rule Notary of the material truth in deed he had made;

- Notary responsibility of duty office by a Notary Code. ${ }^{8}$

Notary responsibilities as public officials include responsibility Notary profession itself related to the deed. In connection with such authority can Notary charged with the responsibility for his actions / her work in an authentic deed. Notary responsibilities as public officials include responsibility Notary profession itself related to the deed, including:

- Notary civilly liable over deed made. The responsibility in this case is the responsibility of the material truth of the deed, in the construction of tort. Unlawful act here in the active and passive nature. Active, in terms of acts that cause harm to others. While passive, in the sense not to do anything that is necessary, so that the other party suffers losses. So the elements of the tort here is the existence of an unlawful act, their mistakes and their losses.

- Notary criminally liable over deed made. Criminal in this case is the criminal acts committed by a Notary in his capacity as a public official authorized to make the deed and not in the context of individuals as citizens in general.

- Notary administratively liable over deed made. Administrative sanctions based on Act No. 22014 says there are five (5) administrative sanctions that can be granted

\footnotetext{
${ }^{5}$ Ngadino, 2019 Tugas Dan Tanggung Jawab Jabatan Notaris di Indonesia, Semarang: UPT Publishing PGRI University Press Semarang, p. 3.

${ }^{6}$ Liliana Tedjosaputro, 1991, Malpraktek Notaris Dan Hukum Pidana, Semarang: Agung, p. 4.

${ }^{7}$ Ngadino, 2019 Op.cit., p.11-12.

${ }^{8}$ Abdul Ghofur Anshori, 2009, Lembaga Kenotariatan Indonesia, Yogyakarta: UII Press, p.16.
} 
Volume 7 Issue 2, June 2020

Nationally Accredited Journal,

Decree No. B/4130/E5/E5.2.1/2019

if a Notary in violation of the provisions of Act No. 2 of 2014, namely: Verbal warning; Written warning; Suspension; Honorable discharge; and Dishonorable discharge.

In other words, deed of Notary has the authentic nature, not by legislation stipulates such, but the deed was made by or in the presence of public officials, as referred to in Article 1868 of the Civil Code.

Based on the above, this research problem is formulated as follows: First how Implementation Responsibility Notaries in Civil Code of the Deed of Authentic are made according to Act No. 2 of 2014 on the Amendment of Act No. 30 of 2004 On Notary in Kendari, Second what are the obstacles and solutions in the Implementation Responsibility Notary Against authentic Deed had made in Kendari.

\section{Research methods}

The method is the basic process of the procedure to find a way out of a problem, while research is a thorough examination on a sign in order to acquire a knowledge of man, the research method can be interpreted as a basic procedure to find a way out the existing problems in carrying out the study. ${ }^{9}$ This research approach is empirical juridical approach.

Specifications of this research is descriptive. The type of data in this study include primary data and secondary data which secondary data obtained from primary legal materials, secondary law and tertiary legal materials.

Primary data in this study was obtained through the method of interviews with relevant parties (informants) the party is the Notary of Kendari, Secondary data were obtained from official documents, books related to the object of research, the results of research in the form of reports, thesis, dissertation, and legislation. ${ }^{10}$ Data analysis techniques used in data processing and data analysis used in this study is qualitative.

\section{Results and Discussion}

\subsection{The Implementation of Legal Responsibilities Of Notary on Authentic Deed Which His Made Based On Act No. 2 of 2014 On the Amendment of Act No. 30 of 2004 On Notary in Kendari}

Every society in both the civil law relations purchase, lease or other legal relationships, of course, preceded by an agreement between the two sides. According to the Subekti agreement is an event where someone promised to others, or where the two are mutually pledge to another person, or in which two people are pledged to carry out something. ${ }^{11}$

In Article 1 point 7 UUJN mention that notarial deed is authentic deed made by or before a notary in the form and manner set forth in this law. This article is an affirmation of article 1868 of the Civil Code which states "an authentic deed is a deed made in the form prescribed by law or before the competent public authority for it in the deed was made". So it was clear that the deed made by the notary is an authentic deed.

\footnotetext{
${ }^{9}$ Soejono Soekanto, 1986, Pengantar Penelitian Hukum, Jakarta: UI Press, p. 6.

${ }^{10}$ Ibid.

${ }^{11}$ Subekti, 2001 Pokok-pokok Hukum Perdata, Intermasa, Jakarta, p. 36.
} 
Based on the article, it is known that the elements in a deed stipulated in Article 1868 of the Civil Code is the deed was made with a form that has been regulated by law, notarial deed was created by or before public officials and also made before officials is authorized to make such deed. Authority to make this Authentic Deed at the request of the parties and the agreement is required for validity on 4 requirements, namely: ${ }^{12}$ Agreement of the parties; Ability to create an engagement; Object / thing that is certain; One reason kosher.

So to an agreement can be said to be a valid agreement, must meet the requirements as stated above.

In principle deed made by the notary an agreement between parties in which notaries only constatire wishes of the parties. What is desired by the parties then pour in the deed which must all conform to the wishes of the parties that have been agreed together. So if one of the parties then feel there are disadvantaged in this regard is the responsibility of the parties is not the responsibility of the notary. Precisely deed made by the notary is evidence that can be used by the parties. Unless there are changes done by a notary without the knowledge of one of the parties is against the law. ${ }^{13}$

In effect the notary deed is legally Authentic Deed which has no probative value was perfect so without presenting the parties or the notary who made the deed can already be categorized evidence was perfect and true. However, if the notary who made it on the need to on ask for information then there is a legal mechanism that must be passed beforehand the Assembly honorary notary (MKN) who has legally set in UUJN Article 66 which required the approval of the Assembly honorary notary (MKN) because it involves the confidentiality of the contents that must be in the said deed by a notary public in providing information. This means that the notary is still obliged to provide information when in need and can not rule violated in giving such information. ${ }^{14}$

Civil liability towards authentic deed made, notary only responsible for the formal correctness of an Authentic Deed and not to the authentic deed material. The legal basis used in civil liability against the deed of Notary is when a Notary to make mistakes because of broken promises as determined under the provisions of Article 1234 of the Civil Code and unlawful acts as defined in Article 1365 Civil Code described "any action against or abuse law resulting in loss of harm to others, require a person who because of his fault publish it or compensate for the loss of the ". Notary who received civil sanctions should be prepared to deal with the claim the injured party, which claim for tort. If further investigation is indeed such actions meet the elements against the law as set forth in Article 1365 of the Civil Code. The article reads: "Each unlawful act and bring harm to others, require a person to incur losses because mistakes to replace these losses". ${ }^{15}$

\subsection{The Obstacles and Solutions in Implementation of Notary Responsibility of the Authentic Deed Which His Made in Kendari}

\subsubsection{Obstacles in the Implementation of Notary Responsibility of the Authentic Deed Which His Made}

\footnotetext{
${ }^{12}$ Article 1320 of the Civil Code

${ }^{13}$ Results Interview with Albert Widya Arung Raya, SH, M.Kn. Notary in Kendari, dated February 10, 2020, At 15:15 pm.

${ }^{14}$ Ibid.

${ }^{15}$ Results Interview with Agus Jaya, SH. Notary in Kendari, dated February 3, 2020, At 13:10 pm.
} 
Obstacles in the implementation of the responsibilities of a notary of the Authentic Deed Which His Made that the good faith of the parties, it is most needed in the manufacturing process in particular notarial deed in the formal presentation of the data by the parties and the submission of the will of the parties ${ }^{16}$ so we must always prioritize the precautionary principle because the information given by the parties are facing may not correspond to the actual that can harm all parties, including the notary itself. $^{17}$

So if one of the parties then feel there are disadvantaged in this regard is the responsibility of the parties is not the responsibility of the notary. Precisely deed made by the notary is evidence that can be used by the parties. Unless there are changes done by a notary without the knowledge of one of the parties is against the law. Then the parties disadvantaged course can sue in civil damages to the notary but it would have to be proven in advance or there are legal provisions which violated or the fulfillment of legal requirements in an authentic deed made by the notary. ${ }^{18}$

\subsubsection{Solutions in the Implementation of Notary Responsibility of the Authentic Deed Which His Made}

Solutions in implementing the notary to civil liability towards authentic deed he made that in the application of the precautionary principle should be run in accordance with the precautionary principle Notary, if established a good relationship, mutual understanding between the Notary and the parties, violations of the law can be avoided. In the precautionary principle in running his notary it is necessary prudence of the notary itself in accepting a job or client. When Notary doubt about the information provided by the parties, as a notary is entitled and obliged to dig up more information for notaries only got formal evidence alone. ${ }^{19}$ Coordination and follow stipulated in the legislation, specifically Article 1320 of the Civil Code and always make priority on principles of prudence and recognition of clients. ${ }^{20}$

If proved, no offense will be undertaken by the notary and harm either party in because a deed in him. The civil claims against the notary concerned civilly liable if proven. ${ }^{21}$ Certainly talk compensation must first be proven legally losses incurred, so that if there is such a thing would advice that can be given is still responsible for any losses incurred. Matter how many losses incurred would be the realm of the court about execution and how responsibility should be met live communication with the parties concerned. ${ }^{22}$

\footnotetext{
${ }^{16}$ Results Interview with Muh. Farid Tahrir Azhari, SH, M.Kn, Notary in Kendari, dated January 20, 2020, $15.00 \mathrm{pm}$

${ }_{17}$ Results Interview with Agus Jaya, SH. Notary in Kendari, dated February 3, 2020, At 13:10 pm.

${ }^{18}$ Results Interview with Albert Widya Arung Raya, SH, M.Kn. Notary in Kendari, dated February 10, 2020, At 15:15 pm.

${ }^{19}$ Results Interview with Agus Jaya, SH. Notary in Kendari, dated February 3, 2020, At 13:10 $\mathrm{pm}$.

${ }^{20}$ Results Interview with Muh. Farid Tahrir Azhari, SH, M.Kn .. Notary in Kendari, dated January 20, 2020, $15.00 \mathrm{pm}$

${ }^{21}$ Results Interview with Albert Widya Arung Raya, SH, M.Kn. Notary in Kendari, dated February 10, 2020, At 15:15 pm.

${ }^{22}$ Ibid.
} 


\section{Closing}

\section{Conclusion}

Based on the research that has been done then the author can draw the conclusion that:

- Implementation of the Notary Responsibility in the Authentic Deed Which His Made, notary only responsible for the formal correctness of an Authentic Deed and not to the authentic deed material. The legal basis used in civil liability against the deed of Notary is when a Notary to make mistakes because of broken promises as determined under the provisions of Article 1234 of the Civil Code and unlawful acts as defined in Article 1365 Civil Code described "any action against or abuse law resulting in loss of harm to others, require a person who because of his fault publish it or compensate for the loss of the deed".

- Obstacles and Solutions in Implementation of Notary Responsibility of the Authentic Deed Which His Made, namely:

- Obstacles in the Implementation of Notary Responsibility of the Authentic Deed Which His Made

When one of the parties then feel there are disadvantaged in this regard is the responsibility of the parties is not the responsibility of the notary. Precisely deed made by the notary is evidence that can be used by the parties. Unless there are changes done by a notary without the knowledge of one of the parties is against the law.

- Solutions in the Implementation of Notary Responsibility of the Authentic Deed Which His Made

If proved, no offense will be undertaken by the notary and harm either party in because a deed in him. The civil claims against the notary concerned civilly liable if proven. certainly talk compensation must first be proven legally losses incurred, so that if there is such a thing would advice that can be given is still responsible for any losses incurred. Matter how many losses incurred would be the realm of the court about execution and how responsibility should be met live communication with the parties concerned.

\section{References}

[1] Abdul Ghofur Anshori, 2009, Lembaga Kenotariatan Indonesia, Yogyakarta: UII Press.

[2] Liliana Tedjosaputro, 1991, Malpraktek Notaris Dan Hukum Pidana, Semarang: Great.

[3] Ngadino, 2019, Tugas Dan Tanggung Jawab Jabatan Notaris di Indonesia, Semarang: UPT Publishing PGRI University Press Semarang.

[4] Soejono Soekanto, 1986, Pengantar Penelitian Hukum, Jakarta: UI Press.

[5] Subekti, 2001, Pokok-pokok Hukum Perdata, Jakarta: Intermasa.

[6] The Civil Code / BW (Burgerlijke wetboek).

[7] Act No. 2 of 2014 on the Amendment of Act No. 30 Of 2004 on Notary.

[8] Wikipedia Indonesia, the Notary, https://id.wikipedia.org/wiki/Notaris Accessed on October 2, 2019 at 1:08 pm. 